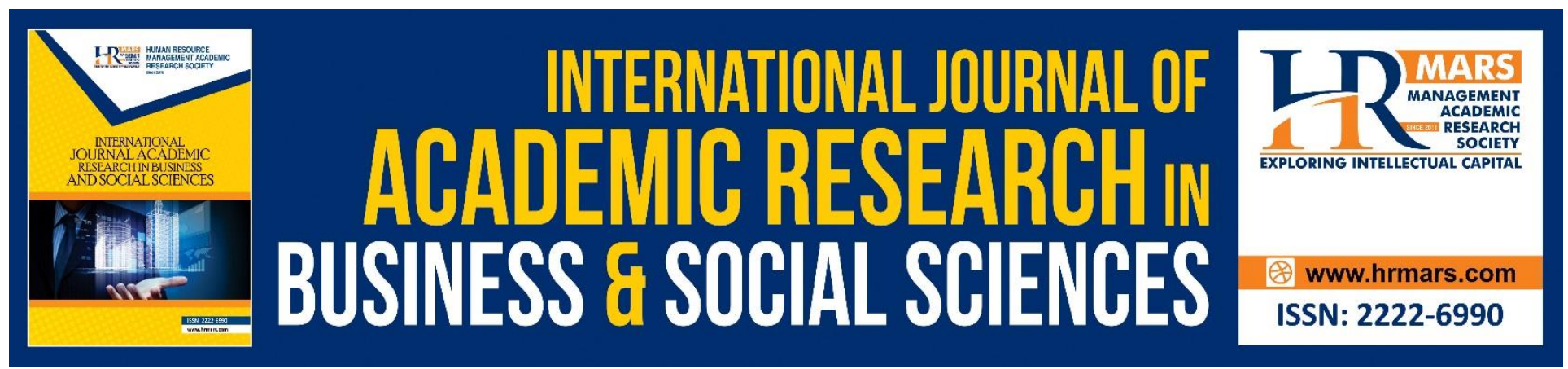

\title{
An Ecofeminist Reading of Christie Watson's Tiny Sunbirds Faraway
}

Ikechi Chioma Elizabeth, Rohimmi Noor and Rosli Talif

To Link this Article: http://dx.doi.org/10.6007/IJARBSS/v10-i9/7723

DOI:10.6007/IJARBSS/v10-i9/7723

Received: 22 June 2020, Revised: 24 July 2020, Accepted: 19 August 2020

Published Online: 18 September 2020

In-Text Citation: (Elizabeth, Noor, and Talif, 2020)

To Cite this Article: Elizabeth, I. C., Noor, R., and Talif, R. (2020). An Ecofeminist Reading of Christie Watson's Tiny Sunbirds Faraway. International Journal of Academic Research in Business and Social Sciences. 10(9), 213-224.

Copyright: (C) 2020 The Author(s)

Published by Human Resource Management Academic Research Society (www.hrmars.com)

This article is published under the Creative Commons Attribution (CC BY 4.0) license. Anyone may reproduce, distribute, translate and create derivative works of this article (for both commercial and non-commercial purposes), subject to full attribution to the original publication and authors. The full terms of this license may be seen

at: http://creativecommons.org/licences/by/4.0/legalcode

Vol. 10, No. 9, 2020, Pg. 213 - 224

http://hrmars.com/index.php/pages/detail/IJARBSS

JOURNAL HOMEPAGE

Full Terms \& Conditions of access and use can be found at http://hrmars.com/index.php/pages/detail/publication-ethics 


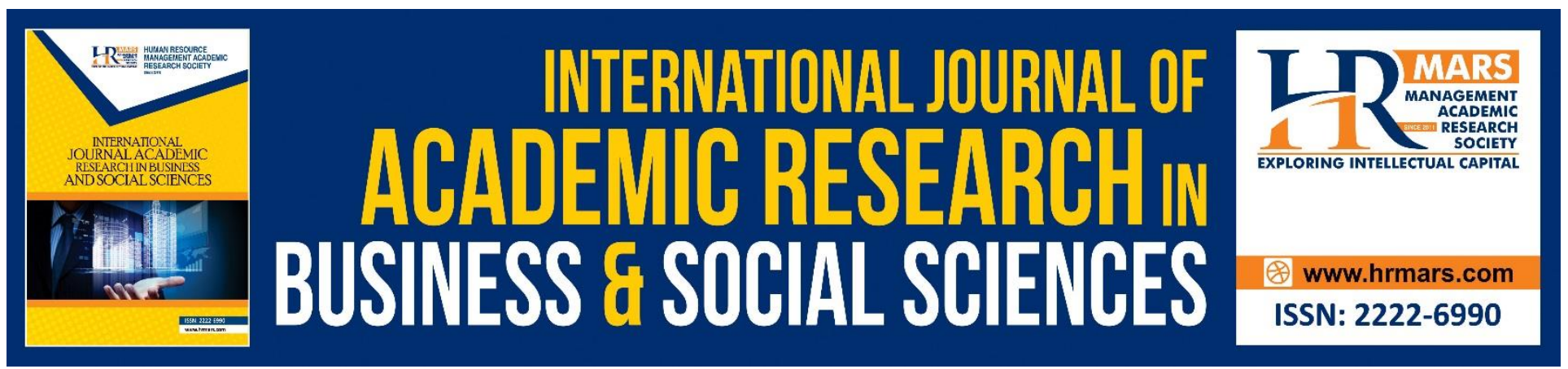

\title{
An Ecofeminist Reading of Christie Watson's Tiny Sunbirds Faraway
}

\author{
Ikechi Chioma Elizabeth, Rohimmi Noor and AP Dr. Rosli Talif \\ University Putra Malaysia (UPM) Seri Kembangan, Selangor, Modern Language and Communication. \\ English Literature. \\ Email: ikechichiomalizzy@gmail.com
}

\begin{abstract}
In the context of the Niger-Delta region of Nigeria, an ecofeminist point of view is vital to unveil the exploitations of the natural environment and its resources, equally examining the connection between women and nature. Focussing on Christie Watson's Tiny Sunbirds Faraway. Published in 2011 whose major part was set in Warri and partly set in Lagos Nigeria. Watson is an Englishwoman married to a Nigerian, her book depict the sober and terrifying moments experienced by women in the African village. This study explores the pattern women are portrayed in the selected novel through the lens of ecofeminism with a view of analysing the processes of women transformation which gave rise to their new identity and equally interprets the female strength in the mist of troubles as they were affected directly and indirectly by the ecological crisis through ecofeminism theory that shows the interconnectedness between women and their natural environment taking Carolyn Marchant concepts of ecofeminism, in her book Radical Ecology $2^{\text {nd }}$ edition published 2005 . However, this study uses the socialist ecofeminism perspective by studying the socio-economic conditions of women in the Niger-delta region of Nigeria and how their lives are affected by the degradation of their natural environment upon which they rely on for survival.
\end{abstract}

\section{Introduction}

Women and the environment are closely bond and interconnected. Throughout history, women have been immortalized as powerful symbols of nature; Ala: Mother earth or Earth Goddess (in Igbo cosmology, as well as other African beliefs), Artemis in the Greek mythology and Mother River (The Yellow River) in Chinese history. Women have personified and given nature its infinite meaning. Therefore, women as bearers and conservers of life, as those who first guide children should be foremost in dedication to the environmental cause.

In the African setting traditionally, most women have been relegated to some roles based on human biological or perceived sex of masculinity and femininity. These roles include fetching water for domestic use, nurturing kids, cooking, farming, getting fire woods for cooking from the forest, fishing etc. all these roles have programmed the woman as 'homemaker' while a man the 'breadwinner'. Going by the position of the woman, it has been presumed that women are supposed to be 
subordinate, emotional, soft, nurturing, caring, submissive etc. While the man is rational, takes decision, strong, protective, superior etc. These roles relegated to the woman have rendered her voiceless even in the face of ecological degradation with the knowledge that she is more affected when the environment is put at risk.

Literary authors today use people's life experiences to portrayed characters in literary works as a medium to address life issues and problems of the environment. The African female writers expressively present their observations of life and even their experiences in the content of their writings making fictions close to reality as portrayed in this study's text. The novel depict various experiences of women being subjugated by men and oppressed by ecological crisis in their environment, thus these stories which portrays triumphant and victimized female characters who courageously battle ecological crisis and patriarchal oppression are the same hailed as strong and indestructible will be analysed in a comprehensive manner with a focus to surface their inner strength and positive threats as well as their struggles.

\section{Theoretical Framework}

Eco-feminism as an ecological feminist movement is discussed at length in Carolyn Marchant $2^{\text {nd }}$ edition Radical ecology published in 2005. Marchant is an American ecofeminist philosopher and historian of science most famous for her theory and book of the same tittle The death of Nature as a professor of environmental history, philosophy and ethics she believes that the age of enlightenment brought in nature degradation. She highlighted different concepts of ecofeminism but the socialist ecofeminism will be the focus for analysing this text.

Socialist ecofeminism is transformed from feminist and socialist ecological movement which assumes that nonhuman nature is the material basis of all of life and that food, clothing, shelter, and energy are essential to the maintenance of human life. It sees the connection of women and nature as practically based on the materialistic tendency of human to exploit nature which leads to the exploitation of women. Many socialist ecofeminist scholars use the concept of the 'capitalistpatriarchy' to describe the manifestation of dominance over women and nature. The likes of Mary Mellor who criticized the world of capitalist "economic man" as one in which some men and some women are liberated at the expense of the rest of humanity and the planet (300).

Therefore, Socialist ecofeminists advocates the liberation of women through overturning economic and social hierarchies that turn all aspects of life into a market society that today even invades the womb.

\section{Methodology}

This study seeks to interpret the strength of a woman in the face of ecological exploitation which led to her emancipation using ecofeminism from the perspective of the selected female writer of the text. It is channelled towards addressing the ecological issues and how it affects women in the Nigerdelta region of Nigeria. As a study in the modern African literature, ecofeminism is considered as a current theory to be employed as an analytical tool for the text. This is in line with the definition of textual analysis put forward by (Frey, Botan \& Kreps, 1999). The analysis will be done in light of socialist ecofeminism (Marchant, 2005 p. 208). The believe in the struggle to end capitalist patriarchal domination of nature and its resources and equally addressing the suppression of women by giving 
INTERNATIONAL JOURNAL OF ACADEMIC RESEARCH IN BUSINESS AND SOCIAL SCIENCES Vol. 10, No. 9, 2020, E-ISSN: 2222-6990 @ 2020 HRMARS

them voice, freedom and most especially empowering them economically in the African society. This is to be achieved by interpreting the novel within the conflict in the growth and development of the African society, dealing with environmental degradation as it affects the female characters and women been exploited in the patriarchal structured society.

\section{Literature Review}

The believe on the notion that men are superior to women have been frequently observed by feminists, which indicate that, the notion was to justify the male control of economic position, political and social powers, in order words to make women powerless by denying them the educational and occupational means of acquiring economic, political and social powers through the application of 'sexism' in the patriarchal favoured society. On this note, ecofeminism cannot be discussed in isolation from feminism and ecocriticism, which will be briefly discussed in this review.

\section{Feminism in Brief}

Feminism could mean different things to different people, going by Lois Tyson's Critical theory today; "feminist criticism examines the ways in which literature (and other cultural productions) reinforces or undermines the economic, political, social and psychological oppression of women (Tyson, 2006, p. 83). The term feminism first emerged in France in the 1880s, then in Great Britain in the 1890s and in the United States in 1910. Feminism main desire is to emancipate women from patriarchal prejudice in all aspects of life which includes; political, cultural, social, educational and economical spheres. According to Hooks, feminism simply put, is a movement to end sexism, sexist exploitation and oppression. Going by this definition, it did not imply that 'men' were the real enemy, practically it denotes that all sexist thinking and action is the real problem, whether those who perpetuate it are female, male, child or adult. (Hooks, 2015, p. 1).

Patriarchy by definition is sexist, which promotes the belief that women are innately inferior to men. It could also be seen as a system in a society in which men dominates and holds power and women are largely excluded from it. This belief is based on the biological difference between the sexes which is considered as part of the unchanging essence of men and women. Feminism therefore distinguishes between the word 'sex', which is referred to the biological constitution of male and female and the word 'gender' which refers to the cultural programming of feminine and masculine.

\section{Ecocriticism in Brief}

Ecocriticism is concerned with the relationships between literature and environment or how man's relationships with his physical environment are mirrored in literature (Roa 46). It is also an umbrella term used to refer to the environmentally oriented study of literature and the art, and the theories that underline such critical practice. It is a new critical method available to critics to analyse literature. It deals with ecological problems like pollution, global warming, climatic change, deforestation, species extinction and other ecological exploitations. Eco-criticism emerged as a study of the relationship between literature and the natural environment in the mid-1990. (Noushad, 2018). It is believed that the term was first coined by William Rueckert in his critical writing "Literature and Ecology: An Experiment in Ecocriticism" in 1978. The word 'eco' comes from the Greek root word 'oikos' which etymologically means household or earth and 'logy' from 'logos' means logical discourse. 
According to Joseph Wood Krutch, Thoreau's work is not about plants or animals or birds; it is about his relation to them; one may almost say about 'himself in connection with nature. Ecology has two shades, the shallow, and the deep ecology. Shallow ecology is essentially anthropocentric, which believes that the whole purpose of nature is to serve mankind and humans are the masters of nature; man being the only literary creature thinks himself superior over the others. It also advocates systematic usages of natural resources like coal, gas, forests, oil, etc. for a sustainable future. But deep ecology challenges this conservation mode and advocates preservation of nature to keep it in its original form without any interference of man, as nature has its own right to survive. All organisms on this earth have their own intrinsic values and no one is the master of anybody. This realization will give equal rights to every organism maintaining a balance in the eco-system. Based on this argument, one would say the real cause of ecological degradation lies in the hand of shallow ecological users.

\section{Concept of Ecofeminism}

Ecofeminism is a movement that sees a connection between the exploitation and degradation of the natural world and the subordination and oppression of women. It emerged in the mid-1970s alongside second-wave feminism and the green movement. It is the coming together of feminism and environmentalism with a concern to establishing the relationship between nature and women with the aim to fighting the degradation of nature and the subjugation of women so as to have more conducive environment

In patriarchal terms, women are synonymous to nature as much as they are closer to nature and men are considered closer and synonymous to culture. Logically, since men are linked to culture and then women to nature, men are superior to both women and nature, this was programmed in order to dominate women and nature. The Western culture holds on this linkage between women, nature, water, and animal so as to emphasise on their inferiority and oppression. This have raised more ecofeminists who attest to the interrelationship between the exploitation of women and nature as they believe that the inferiority of women and nature is a discursive social construct which is dominant in patriarchal cultures. To prove this, Gaard has this to say, "reality is divided according to gender, and a higher value is placed on those attributes associated with masculinity, a construction that is called 'hierarchical dualism' (Gaard 1993, p. 18).

From the forgoing discussions, it is clear that the ecofeminists stand point is a world balanced in ecosystem and free from all patriarchal structures. Patriarchy should have no place in the contemporary environmentalist struggle to free women and nature from domination. There should be an interdependency in place of social hierarchies of domination which should be expressed between men, women and the ecosystem at large which will lead to the needed balance in nature for the coexistence of all life on earth.

\section{About the Author of the text; Christie Watson}

Christie Watson's Tiny Sunbirds Far Away won the Costa First Novel Award in 2011 and has since remained reckonable when mention is made on books written by foreigners about African or events within its confines. But Christie, despite being a Briton, is no stranger to Nigeria, her setting for the book. She's married to a Nigerian and is as such, attune with some cultural backgrounds she tried to project in the work. She is also the writer of; Where women are kings (2014), Here I stand (2016) and The Language of Kindness (2018). 
INTERNATIONAL JOURNAL OF ACADEMIC RESEARCH IN BUSINESS AND SOCIAL SCIENCES Vol. 10, No. 9, 2020, E-ISSN: 2222-6990 @ 2020 HRMARS

\section{Plot Summary of the Text}

Tiny Sunbirds Faraway begins fully when their mother catches their father with another woman, twelve-year-old Blessing and her fourteen-year-old brother, Ezekiel, are forced to leave their comfortable home in Lagos for a village in the despoiled Niger Delta, to live with their mother's family. Without running water or electricity, Warri is at first a nightmare for Blessing. Her mother is gone all day and works into the night to pay the children's school fees. Her brother, once a promising student, seems to be falling increasingly under the influence of the local group of violent teenage boys calling themselves Freedom Fighters. Her grandfather, a kind of misguided man, is trying on Islam as his new religion of choice, and is even considering the possibility of bringing in a second wife to bear him male children.

But Blessing's grandmother, wise and practical, soon becomes a beloved mentor, teaching Blessing the ways of the midwife in rural Nigeria. Blessing is exposed to the horrors of genital mutilation and the devastation wrought on the environment by British and American oil companies. As Warri comes to feel like home, Blessing becomes increasingly aware of the threats to its safety, both from its unshakable but dangerous traditions and the relentless carelessness of the modern world.

Absorbing and passionate and set in the Niger Delta, Tiny Sunbirds Faraway is the witty and beautifully written story of one family's strive to survive a new life they could never have imagined, struggling to find a deeper sense of identity along the way.

\section{Discussion/Findings}

The Niger-delta experienced oil boom and due to continuous exploitation and exploration, the environment became degraded. Watson's Tiny Sunbirds Far Away tells the story of a women, and her children in Niger-Delta, using Warri as the primary setting. Through the character of a little girl Blessing, the narrator tells the story of how women in the degraded Warri are pushed to face ecological problems while supporting their families.

In the narrative, both nature and women are dominated, controlled and exploited by the locals (politicians, government and community elders) and Western Oil Company workers in the community. Both women and nature are controlled by men in the narrative as they detect what happens to women and nature while exploiting them for their cultural and chauvinistic purpose. It is on this note that the novel starts from Allen Avenue in Lagos; a notorious street polluted by various filthy activities. Apart from the uncontrolled commercial activities in the Allen Avenue, the street is polluted by constant use of noisy and faulty generators, noise from auto mobiles, and germs from the market.

The environment presented is characterized by physical, celestial and psychological pollution. The noise affects the characters' psyche while the illegal commercial activities such as prostitution and countless pubs expose them to the ills of the society. It is on this note that, Father who is a typical Lagos man was able to manoeuvre Mama, drinks constantly, staggers, and flirts with other women. Blessing describes her Father:

Father was a loud man. I could hear him shouting from the neigbours' apartment where he argued about football with Dr. Adeshina, and drunk so much Remy Martin that he could not stand up properly. I could hear him singing when he returned from the Everlasting Open Hands House of Salvation Church, on a bus that had the words 'UP JESUS DOWN SATAN' written on the side. The singing will reach my ear right up on the fourth floor. From my 
INTERNATIONAL JOURNAL OF ACADEMIC RESEARCH IN BUSINESS AND SOCIAL SCIENCES Vol. 10, No. 9, 2020, E-ISSN: 2222-6990 @ 2020 HRMARS

window, I watched the bus driver and Pastor King Junior Carry Father towards the apartment because he could not stand up at all (8).

As a character in the notorious Allen Avenue, Father is affected by the environmental pollution, being physical or psychological but it is Mama who suffers the damage. She struggles to distance the children from being damaged by father and the activities in the Allen Avenue. It is on this note that the narrator concludes that "Father was a loud man but it was Mama who was screaming" (9). This indicates that while Father is living "loud" lifestyles, and allowing his environment to corrupt his psyches, it was Mama who "screams". Screaming in this context denotes an expression of deep pain as a result of being the primary victims of Father's and Allen Avenue's loudness. Also, the apt portrayal of "bed" in the narrative as being polluted by Father's amorous lifestyles shows that bed is like nature. The family peace and love revolve around the bed, which is similar to the centeredness of nature in Niger-delta. When the bed like the land is degraded, the family started to live in shambles, and Mama was abandoned by Father the way multinational companies who exploit the environment abandon her after degradation.

This shows the relationship between women and nature, nature is a symbol of a woman, they share same predicament looking at the case of Mama in the text, especially in being dominated, exploited and abandoned. Mama as a single mother was sacked by Royal Imperial Hotel, on the grounds of being divorced. The narrator captures it aptly: "It was a month after that when Mama had to stop working at the Royal Imperial Hotel. She said that the owners only employed married women. Since Father had left, I did not dare ask her anything at all" (10-11).

Ecofeminism adopts the assumptions of ecocriticism and feminism, hence the above except illustrates that the African society is dominated by men, and the value of a woman is determined by a man that she attaches herself to. This explains why Mama is valueless when Papa left. The hotel could no longer keep her because she is not attached to any man. Moreover, the landlord will not allow her to stay since she can't afford the rental of the house. without a husband and without a job she migrated to Warri with her children. At this stage, Mama becomes an object, and even at Warri, the novel's second setting, she needs to be attached to both Alhaji and Dan to survive. She must care for Blessing and Ezikiel. She must perform her duty as both father and mother.

Her migration from polluted Allen Avenue to Warri, a war zone characterized by constant conflict and filthy activities by oil companies shows that she is handicapped, and ready to face life. Mama, as a depressed character, recognises the dangers of migrating to Warri but was left with no option. Ezikiel asserts that because the environment has been polluted by the multinational company through their activities in the region, surviving there will be difficult for them.

This is also the argument of Gaard (1993); Darwish, Abdo, \& AlShuwaiee, (2018) that oppression on nature is also oppression on women, and thus nature cannot be liberated without looking how the degraded nature affects women, children, animals and men that are also vulnerable. Through Ezikiel, the writer highlights: "It's dangerous. The whole Delta region. And if we don't get shot the bacteria and parasites will surely kill us" (12). This carries specially the image of a dead zone and anyone who goes there is on a suicide mission. A paradise turned to hell by the activities of humans becomes more dangerous because man's activities in the region are not controlled and Mama who was abandoned by her husband became depressed but must look for a new living for the family which made her the primary victim and she got trapped in the polluted Warri environment with her children.

At Warri, the family is expected to battle parasites, polluted water, farm lands, and countless political crises. They will also struggle to survive in an environment without the basic social amenities and 
INTERNATIONAL JOURNAL OF ACADEMIC RESEARCH IN BUSINESS AND SOCIAL SCIENCES Vol. 10, No. 9, 2020, E-ISSN: 2222-6990 @ 2020 HRMARS

infrastructures they were used to in Lagos. The state of Warri is argued to be caused by the malhandling of the environment and the circumstance that led to the forced migration is caused by Father but it is Mama and the vulnerable children who suffer from the disasters.

Mama, Blessing and Ezikiel are presented by the author as product of dual exploitation, and they embody the image of women, and vulnerable children in Niger-Delta. Ezekiel laments: “'Do you know where we are moving? It's the parasites you should be worried about. What about my allergies? That place is so bush. I doubt they even have medical facilities" (13). This foreshadows the state of things at Warri. The author uses this to vividly narrate the nature of suffering and pain that Mama is forced to live with as a result of Father's abandonment. It also shows that while the characters at Allen Avenue suffer mostly from pollution from the noise of cars, generator and immoral activities of whores, at Warri, they will be faced with more dangerous environmental disasters. One can therefore argue that if the degraded Allen Avenue, which is the first setting of the novel render the character's homeless and fatherless then the second setting which has been permanently destroyed will hold more danger for them.

At Warri, the three characters are forced to live a different and hard life presented to them by the environment. There is no electricity or generator, no good road, no good water, and not even a safe environment which is different from life at Allen Avenue, the characters must adapt to Warri's lifestyle.

Warri as part of Niger-Delta produces wealth for the Nation as they are rich in natural resources yet life there becomes lifeless for the average people in Warri, the characters live in poverty, fear of violence, and absolute contaminated environment. This in turn proves the socialist ecofeminist point, as Marchant state quoting Engels thus: "When we ignore the consequences of our interaction with nature Engels warned, our conquest "take...... revenge on us." (209).

Warri portrays the picture of a region that is exploited, degraded and abandoned. Blessing referred to the water of Delta as the "blood of Nigeria" (31). These descriptions of water as blood indicates that the water was in its original state and was well taken care of before the coming of the Western Oil company in to the environment to pollute the water now the struggle of the people in the environment to maintain their natural resources was dashed to the ground by the expatriates who took their effort for granted by polluting their environment and leaving them with nothing but crisis and diseases.

As Mama decided to get a job to support the family given the very fact that Alhaji cannot take care of the family and uses the little money in his possession to marry a second wife Celestine. Mama was employed by same Western Oil Company that polluted the environment. Celestine took up the job of a 'town mourner' because of the numerous death caused by the polluted environment. Like other locals, Mama was employed as a waitress. This validates Ahmed Yerima's assertion in an interview with Gbemisola Adeoti's that "oil is like kolanut, the people who grow it are different from people who eat it" (115). Mama's description of the compound of the Western Oil Company as a paradise shows the contrast between those who grow the oil, and those who eat it. Mama narrates:

The Highlife Bar. The oil workers go there to watch the wildlife as much as drink. From the table we were sitting at I could see a troop of monkeys travel across the trees. It's like a national park. Honestly, I can't believe that the other side of the wall is another world. One minute you're in oily swamp, the next, five-star luxury. Cool, air- conditioned, five-star luxury (80) 
INTERNATIONAL JOURNAL OF ACADEMIC RESEARCH IN BUSINESS AND SOCIAL SCIENCES Vol. 10, No. 9, 2020, E-ISSN: 2222-6990 @ 2020 HRMARS

This reflects the contradistinction between the swampy Warri, and luxurious environment enjoyed by the oil workers. Being employed by same company who polluted the land puts her in another danger. It was at the bar that she met Dan, a white man who Ezikiel see a double oppressor. Dan like other foreigners in Niger-Delta Literature pretends to take care of their preys while they indirectly exploit them. Dan was a good example of this assertion, he takes care of Mama and the family while he is also part of the problem of the environment as he benefits from their activities in the environment to the peril of other citizens in the community. This made Ezikiel reprimand him when he offered him a gift of a chocolate bar in one of his visits thus; "You give me a chocolate bar? A chocolate bar? Offer to help me find a school. Well, instead of that, I'd prefer my country back please (269)". He further adds:

You people come here, Ezikiel slammed his fist down onto the table top, making us all jump, and take over our women, he looked at Mama, and our money. And our jobs. He looked at Alhaji. Nobody moved. You pay people to kill us and rape our land, then our women! And you give me a chocolate bar? (270)

Ezikiel represent the people of the Niger delta, Watson uses to highlight how the Western Oil Company through the help of the government exploit the poor masses, their lands, their jobs and also their women. To Ezikiel, Dan is not different from other oppressors. He is like other expatriates and must be stopped from degrading the environment, women and vulnerable children. This led him to join the "Sibeye Boys", the local militant group in the region who among other groups fight for the justice of the environment through violence as they believed it is only through violence that justice could be achieved since several appeals to the government and the expatriates have failed.

The remoulding of Ezikiel from being the book-loving child, full of dreams of becoming a medical doctor in the future to joining the Sibeye boys and attacking his mother's fiancée Dan is instigated by the condition meted on him by the environment, where few privileged ones enjoy the benefits in the community while the poor suffers. This condition alone shaped the way Ezikiel thinks seeing the luxury life Dan displayed which lured his mother to him so as to help the family, he presents himself as the Niger-delta people demanding for justice of their land. The city of Lagos where they migrated from, have its own dirty and corrupt sides but not in comparison to the Warri village that is described as a dead zone and not conducive for human beings especially for a child like him who suffers allergies.

The change in Ezikiel's character greatly affected Mama as that was not her plans for her son but she must put her emotions aside so as to survive and carter for her children. Her relationship with Dan the expatriate made Blessing and Ezikiel preferred having their father back to having Dan. Thus; "We don't want a white father. What was she thinking?' Ezikiel began to cry. We want our father back." (349). Seeing Dan Marry their mother against their wish, Ezikiel felt defeated and planned for his kidnap through the help of the Sibeye boys.

The Sibeye Boys is a militant group of boys measured within Ezikiel's age grades who uses violence against the oil company in demand for environmental justice. The context of situation that led Ezikiel to joining the local militant group represent the situation they are faced with and their fight for equity to matters concerning the environment with the believe that justice on the environment determines the future of everybody in the community. The oil exploration and exploitation in the local community becomes noticeable when pollution in the environment becomes unbearable thereby causing death, poverty, diseases, deformation of children and formation of militant groups who 
perpetuate violence in the cause of fighting for justice. Only the wealthy or the privileged ones can survive these crises, women and vulnerable children becomes the victims at this point.

The destruction created in the environment by the expatriates lured the youth into violence by creating different militant groups as a way of stepping in into their environmental matters to intervene, though some of the groups were sponsored by the politicians like the Sibeye boys (186) in contrast to the real Freedom fighters of the Izon nation (FFIN). The violence of these different groups together with the disruptions cause by the Western Oil Companies results to joint forces environmental destruction which placed the environment and its inhabitants at a very high risk. The land, air and waters becomes polluted affecting women and children at most. This made Blessing wonder how women manage to take their bath in the water filled with oil spill as she sees it as meaningless (31).

Blessing realises the effect of environmental pollution especially on women when she started following her grandmother to attend to birth in the local community, from what she discovered she told her brother Ezikiel who was able to speak up on the effects of the environmental pollution in the meeting held in Alhaji's compound thus:

"Gives us respiratory diseases, cancers, makes our women suffer miscarriage, and make our children deformed! Some of the stories I hear from my own sister, who is an Assistant Birth Attendant, prove that the air is poisoning our women!" (188)

From the excerpt above one would discover that the fate of women in such environment is one that is disastrous especially in a situation where the oil company bribes the government and some of the community elders to allow them burn poisonous gases and destroy the local environment thereon women and children becomes mostly the victims in such circumstances.

In Ezikiel's quest to get back at Dan the same measures on what the Western Oil Company did to their environment, he joined the boys to sabotage the oil pipeline which led to an explosion that caused his death and several others in turn leaving Mama and Blessing in a traumatic state.

The text clearly pointed out the plight of women and children in the polluted Warri environment and how only the rich survives and even sell to the poor as Grandma describes the owner of the borehole water where they all buy water. "The owner of the borehole is a rich man. He has satellite television!" (73). An observation on the text clearly point to the fact that the ongoing crisis didn't meet its resolution instead it got worsened by the day and emancipation becomes solely an individual determination and choice just like the path Blessing who is the protagonist took to emancipate herself.

For Blessing, her stages to maturity and growth was liberating. She went from been addressed as "Just a girl" (183) to a grown woman. As a birth attendant in the local community, taking her Grandmother's footstep despite the environmental crisis and the poverty she faced in Alhaji's house. Being a promising young girl she dropped out of school in order for her brother to continue as Mama couldn't afford to pay for both of them. Blessing went on in assisting her Grandmother in local midwifery against her mother's opinion. On this note she feels liberated from the violence and destructions that constitute her community, saving lives through attending birth was a means of contributing meaningfully to the society considering the fact that the local women in the community were mostly farmers, fisher women and too poor to get access to the basic health care they needed as even most of their sources of livelihood were destroyed by the pollution in the environment. Basically, they pay in exchange for the services they get from her in fishes and food stuffs. 
Considering the situation that surrounds the Niger-delta region as displayed in the novel, women engages themselves in positive, helpful and advantageous jobs so as to liberate themselves from the happenings in the environment. Just like Celestine, Blessing and her Grandmother. Celestine Alhaji's junior wife took up a job as a town mourner, she was able to be constructive on the kind of job that suit the environment taking into consideration the warring, diseases and deaths that recurrently happens in the environment (126).

Blessing and her Grandmother gave their attention to attending to birth despite being paid in little or nothing, this was a means of helping procreation and reproduction. One would deduce that by attending to birth they equally attends to nature and posterity purposes. Blessing and her Grandmother portrays the strength of women in the face of crisis, despite being in the environment that is full of violence, destruction, poverty and diseases they still find a means to liberate themselves and also help others by making their practical activities in the local community valuable, encouraging and beneficial to the wellbeing of humanity in the environment where they find themselves.

\section{Conclusion}

Watson did not only explore the ecofeminist premise in the text but she also seeks the possible solution towards women emancipation in the environment. Which was portrayed by the narrator 'Blessing' who took after Grandma in local midwifery. The situation surrounding the death of Ezikiel clearly pictures to the mind the aftermaths of degradation that grew from the exploitation of nature which could spread to the future if not stopped and advises humans to work within the limit of nature. Therefore, the ecofeminist paradigm advises that only through changing our activities with nature and working in harmony with nature, by so doing we can contribute to the well-being of the ecosystem thereby empowering individuals towards a sustainable environment where everyone will be safe.

This study will contribute to the body of knowledge in a significant way as it will help educate people passing through one form of environmental violence and pollution or the other. According to my findings, in the mist of all these troubles that surrounds the victims, instead of feeling devastated or depressed, the female victims empowered themselves and used their situation to a good advantage not just for themselves but for their local community at large. For example, Celestine who saw the warring and numerous death in the environment decided to be a "Town Mourner" and she gets paid after each funeral she attends to mourn. She became relevant in Alhaji's family as her contribution in Ahaji's family became fulfilling to her. She was no longer beaten and insulted by Alhaji for being good for nothing in his house. The same applied to Grandma, Blessing and Mama as depicted in the text.

Therefore, this study will educate not just women alone but the society on how to be useful to their environment and increase their standard by copying the examples of the female characters in the text to a good advantage of their environment just like Marchant's ecofeminist theory advises everyone to work in harmony with the environment as failure to do that, the environment will take conquest on it inhabitants (300).

\section{Works Cited}

Darwish, S., Abdo, H., \& AlShuwaiee, W. M. (2018). Opportunities, challenges and risks of transition into renewable energy: the case of the Arab Gulf Cooperation Council. International Energy Journal, 18(4). 
INTERNATIONAL JOURNAL OF ACADEMIC RESEARCH IN BUSINESS AND SOCIAL SCIENCES

Vol. 10, No. 9, 2020, E-ISSN: 2222-6990 @ 2020 HRMARS

Gaard, G. (1993). Ed. Ecofeminism: Women. Animals, Nature, Temple University press USA, Print. Hooks, B. (2015). Feminism Is for Everybody. Abingdon-United Kingdom, United Kingdom, Routledge. Mellor, M. (1998). Feminism and Ecology: An Introduction. NYU Press, Print.

Merchant, C. (2005). Radical Ecology: The Search for a Livable World (Revolutionary Thought and Radical Movements). 2nd ed., Routledge.

Noushad, P. M. (2018). "Eco-criticism, Eco-theory and Teaching of literature." Journal of english language and literature (joell), 5(4), pp. 66-68.

Rao, R. (2016). "A Study of Ecofeminism in the Novel Mistress of Spices." IOSR Journal of Humanities and Social Science, 21(11), pp. 46-49.

Tyson, L. (2006). Critical Theory Today: A User-Friendly Guide. 2nd ed., Routledge.

Watson, C. (2011). Tiny Sunbirds, Far Away: A Novel. 0 ed., Other Press.

Yerima, A. (1989). "The Guerilla Theatre as a Tool for National Re-awakening: A Study of the Soyinka's Experience". Literature and National Consciousness. Ed. Ernest Emenyonu. Ibadan: Heinemann, 180-195. Print.

\section{Authors' Brief Biography}

Ikechi Chioma Elizabeth is a Masters student of English Literature in Universiti Putra Malaysia, under the supervision of Rohimmi Noor and AP Dr. Rosli Talif, in the Department of English, Faculty of Modern Languages and Communication. Her main area of research is Ecofeminism in African literary writings as regards to women fiction especially the situation in the Niger-delta region of Nigeria.

Rohimmi Noor is a senior lecturer at the Department of English, Faculty of Modern Languages and Communication, University Putra Malaysia. His research interests include literary criticism and new Literatures in English.

AP Dr. Rosli Talif is an Associate Professor and currently the Head of the Department of English, Faculty of Modern Languages and Communication, Universiti Putra Malaysia. He has published books and journal articles in literature and applied linguistics. 